\title{
Impact of Sustainable Manufacturing Practices on Financial Performance of MSME in Coimbatore District
}

\begin{abstract}
Sustainable manufacturing practices are described from an environmental angle, with the objective of minimization of effects of manufacturing activities on environment with best performance of firms. The adoption of sustainable manufacturing practices is not only concentrating on large sized manufacturing firms but also on Micro, Small and Medium Enterprises (MSMEs). Significant difference is prevailing amongst profile of MSMEs and their sustainable manufacturing practices. Cleaner production, eco-efficiency, relation with supplier, relation with employee and relation with customer are having significant and positive impact on financial performance of MSMEs. To improve sustainable manufacturing practices, MSMEs should reduce their solid waste and usage of materials and they must have efficient compliance for environment and adopt environment regulations properly. Furthermore, MSMEs should provide sufficient salary and good work life balance to their employees and they must direct suppliers to act on environment problems and send appraisal of environmental performance to them and these measures will improve financial performance of MSMEs.
\end{abstract}

S. Rani
Keywords-Financial Performance, MSMEs, Sustainable Manufacturing Practices

\section{INTRODUCTION}

Presently, manufacturing industry is transformed swiftly because of increasing consciousness of sustainable manufacturing operations. As a result, manufacturing firms are adopted different sustainable practices to decrease carbon emission, stay competitive and as a solution to degradation of environment. (Despeisse et al 2012). The primary principle of sustainable manufacturing practices is its relation with performance of firms in long term (Lopez-Amero et al 2009). Sustainable manufacturing practices are described from an environmental angle, with the objective of minimization of effects of manufacturing activities on environment with best performance of firms (Nordin et al 2014). The major environmental sustainability practices used in manufacturing firms are use of renewable energy, optimization of materials, recycling of waste, environmental design, and management of product and minimization of solid wastes (Alay et al 2014).

The adoption of sustainable manufacturing practices is not only concentrating on large sized manufacturing firms but also on Micro, Small and Medium Enterprises (MSMEs) (Jamian et al 2012). Sustainable manufacturing practices in MSMEs influence environmental, financial and operational performances (Chen and Shih, 2007). MSMEs have a significant place in the industrial structure of India and also in Tamil Nadu. Coimbatore district is highly industrially developed and energetic districts in Tamil Nadu and it has high concentration of MSMEs. Therefore, it is necessary to study impact of sustainable manufacturing practices on financial performance of MSMEs in Coimbatore district.

Revised Manuscript Received on December 16, 2019.

*Dr. S. RANI, Department of Commerce, Kalasalingam Academy of Research and Education, Krishnankoil, India. Email:rani.s@klu.ac.in

\section{REVIEW OF LITERATURE}

Millar and Russell (2011) found that sustainable manufacturing practices were significantly and positively related with performance, but they were not related with competitive advantage of firms. Schoenherr and Talluri (2012) concluded that sustainable environmental manufacturing practices were influencing performance and competitiveness of manufacturing firms.

Joung et al (2013) revealed that financial growth, social welfare, management of environment and clear technologies were positively and significantly related with performance of firms. Russell and Millar (2014) indicated that negative and significant relation was prevailing among sustainable manufacturing practices and business performance and significant and positive performance was there among sustainable manufacturing practices and competitive advantage of firms.

Fadly et al (2015) showed that supply chain management, process for manufacturing, management of environment and social responsibility were sustainable manufacturing practices adopted by automobile firms. Nordin and Adebambo (2016) found that economic growth, environment stewardship and social well being were sustainable manufacturing practices used in manufacturing firms.

Hashidah et al (2017) concluded that sustainable manufacturing practices were positively related with economy sustainability performance of firms. Hami et al (2018) revealed that clean production, eco-efficiency, relation with customer, supplier and customer were sustainable manufacturing practices adopted by small and medium enterprises.

\section{METHODOLOGY}

The present study is done Coimbatore district. MSMEs are selected by using simple random sampling method and structured questionnaire is used to collect data from 250 MSMEs. Percentages are calculated to know profile of MSMEs and mean and standard deviation are worked out to understand sustainable manufacturing practices in MSMEs. t-test and F-test are done to scrutinize difference amongst sustainable manufacturing practices and profile of MSMEs. Multiple regression analysis is used to evaluate impact of sustainable manufacturing practices on financial performance of MSMEs. 


\section{RESULTS AND DISCUSSION}

\section{A. PROFILE OF MSMES}

The profile of MSMEs is given in Table-1. The findings explain that 64.40 of them are running as sole proprietorship, whilst 35.60 per cent of them are running as partnership and 37.20 per cent of them are having investment of Rs.10,00,001 - Rs.20,00,000, whilst, 6.80 per cent of them are having investment of more than Rs.40,00,000. The findings display that 50.40 per cent of them are operating in leased establishments, whilst, 23.20 per cent of them are operating in rented establishments and 28.00 per cent of them are providing employment to $11-20$ employees, whilst, 20.80 per cent of them are providing employment to above 30 employees. And 44.00 per cent of them are having annual turn over of Rs.5,00,001 - Rs.10,00,000, whilst, 22.40 per cent of them are having annual turn over of more than Rs.10,00,000.

\begin{tabular}{|c|c|c|}
\hline Profile MSMEs & Number of MSMEs & $\begin{array}{l}\text { Percentag } \\
\text { e }\end{array}$ \\
\hline \multicolumn{3}{|l|}{ Nature of Ownership } \\
\hline Sole Proprietorship & 161 & 64.40 \\
\hline Partnership & 89 & 35.60 \\
\hline \multicolumn{3}{|l|}{ Investment } \\
\hline Less than Rs. $10,00,000$ & 41 & 16.40 \\
\hline $\begin{array}{ll}\text { Rs. } 10,00,001 \\
\text { Rs.20,00,000 }\end{array}$ & 93 & 37.20 \\
\hline $\begin{array}{ll}\text { Rs. } 20,00,001 \\
\text { Rs. } 30,00,000\end{array}$ & 54 & 21.60 \\
\hline $\begin{array}{ll}\text { Rs. } 30,00,001 & - \\
\text { Rs. } 40,00,000\end{array}$ & 45 & 18.00 \\
\hline More than Rs.40,00,000 & 17 & 6.80 \\
\hline \multicolumn{3}{|l|}{$\begin{array}{l}\text { Business } \\
\text { Establishment }\end{array}$} \\
\hline Own & 76 & 30.40 \\
\hline Leased & 116 & 50.40 \\
\hline Rented & 58 & 23.20 \\
\hline \multicolumn{3}{|l|}{ Number Employees } \\
\hline Below 10 & 59 & 23.60 \\
\hline $11-20$ & 70 & 28.00 \\
\hline $21-30$ & 69 & 27.60 \\
\hline Above 30 & 52 & 20.80 \\
\hline \multicolumn{3}{|l|}{ Annual Turnover } \\
\hline Less than Rs.5,00,000 & 84 & 33.60 \\
\hline $\begin{array}{l}\text { Rs. } 5,00,001 \\
\text { Rs. } 10,00,000\end{array}$ & 110 & 44.00 \\
\hline More than Rs. $10,00,000$ & 56 & 22.40 \\
\hline
\end{tabular}

The sustainable manufacturing practices in MSMEs were studied and the results are given below.

\section{A.CLEANER PRODUCTION}

The cleaner production in MSMEs is given in Table-2. Table-2. Cleaner Production

\begin{tabular}{|l|l|l|}
\hline Cleaner Production & $\begin{array}{l}\text { Mea } \\
\mathbf{n}\end{array}$ & $\begin{array}{l}\text { Standa } \\
\text { rd } \\
\text { Deviati } \\
\text { on }\end{array}$ \\
\hline Use of clean technologies & 3.82 & 1.03 \\
\hline Reduction of solid waste & 3.26 & 1.14 \\
\hline $\begin{array}{l}\text { Decrease in consumption of } \\
\text { energy }\end{array}$ & 3.74 & 1.07 \\
\hline Lessening of emission & 3.79 & 1.05 \\
\hline Reduction in usage of materials & 3.35 & 1.10 \\
\hline
\end{tabular}

MSMEs are agreed with use of clean technologies, decrease in consumption of energy and lessening of emission,

\section{B. SUSTAINABLE MANUFACTURING PRACTICES IN MSMES}

while, they are neutral with reduction of solid waste and reduction in usage of materials.

\section{B. ECO-EFFICIENCY}

The eco-efficiency in MSMEs is given in Table-3.

Table-3. Eco-Efficiency

\begin{tabular}{|l|l|l|}
\hline Eco-Efficiency & Mean & $\begin{array}{l}\text { Standard } \\
\text { Deviatio } \\
\text { n }\end{array}$ \\
\hline Recycling of waste materials & 3.76 & 1.08 \\
\hline $\begin{array}{l}\text { Environmental enhancement through } \\
\text { cross functional activities }\end{array}$ & 3.72 & 1.10 \\
\hline Compliance for environment & 3.32 & 1.13 \\
\hline Quality management of environment & 3.78 & 1.04 \\
\hline Adoption of environment regulations & 3.30 & 1.14 \\
\hline
\end{tabular}

MSMEs are agreed with recycling of waste materials, environmental enhancement through cross functional activities and quality management of environment, while, they are neutral with compliance for environment and adoption of environment regulations.

\section{RELATION WITH EMPLOYEE}

The relation with employee in MSMEs is given in Table-4.

Table-4. Relation with Employee

\begin{tabular}{|l|l|l|}
\hline Relation with Employee & Mean & $\begin{array}{l}\text { Standard } \\
\text { Deviatio } \\
\text { n }\end{array}$ \\
\hline Safety measures & 3.86 & 1.05 \\
\hline Sufficient salary & 3.38 & 1.11 \\
\hline Personal development & 3.83 & 1.11 \\
\hline Encouragement & 3.85 & 1.07 \\
\hline Good work life balance & 3.34 & 1.14 \\
\hline
\end{tabular}

MSMEs are agreed with safety measures, personal development and encouragement, while, they are neutral with sufficient salary and good work life balance.

\section{RELATION WITH SUPPLIER}

The relation with supplier in MSMEs is given in Table-5. Table-5. Relation with Supplier

\begin{tabular}{|l|l|l|}
\hline Relation with Supplier & Mean & $\begin{array}{l}\text { Standard } \\
\text { Deviatio } \\
\text { n }\end{array}$ \\
\hline $\begin{array}{l}\text { Selection supplier based on environmental } \\
\text { standards }\end{array}$ & 3.70 & 1.06 \\
\hline Environmental programmes for suppliers & 3.68 & 1.12 \\
\hline $\begin{array}{l}\text { Directing suppliers to act on environment } \\
\text { problems }\end{array}$ & 3.36 & 1.14 \\
\hline $\begin{array}{l}\text { Communicating suppliers on advantages of } \\
\text { clean technologies }\end{array}$ & 3.77 & 1.09 \\
\hline $\begin{array}{l}\text { Appraising environmental performance of } \\
\text { suppliers }\end{array}$ & 3.31 & 1.16 \\
\hline
\end{tabular}

MSMEs are agreed with selection supplier based on environmental standards, environmental programmes for suppliers and communicating suppliers on advantages of clean technologies, while, they are neutral with directing suppliers to act on environment problems and appraising environmental performance of suppliers.

\section{E. RELATION WITH CUSTOMER}

The relation with customer in MSMEs is given in Table-6

Published By: 
Table-6. Relation with Customer

\begin{tabular}{|l|l|l|}
\hline Relation with Customer & Mean & $\begin{array}{l}\text { Standard } \\
\text { Deviatio } \\
\mathbf{n}\end{array}$ \\
\hline Eco-friendly waste management & 3.90 & 1.03 \\
\hline Eco-friendly packaging & 3.94 & 0.95 \\
\hline Eco labeling & 3.91 & 0.99 \\
\hline Complete avoidance of harmful effects & 3.28 & 1.12 \\
\hline $\begin{array}{l}\text { Incorporation of feedback into } \\
\text { manufacturing activities }\end{array}$ & 3.88 & 1.06 \\
\hline
\end{tabular}

MSMEs are agreed with eco-friendly waste management, eco-friendly packaging, eco labeling and incorporation of feedback into manufacturing activities, while, they are neutral with complete avoidance of harmful effects.

\section{B. SUSTAINABLE MANUFACTURING PRACTICES AND PROFILE OF MSMES}

To scrutinize difference amongst sustainable manufacturing practices and profile of MSMEs, t-test and ANOVA (Analysis of Variance) test are done and the results are given in Table-7.

Table-7. Difference amongst Sustainable Manufacturing Practices and Profile of MSMEs

\begin{tabular}{|c|c|c|}
\hline Particulars & $\begin{array}{l}\text { t-Value / } \\
\text { F-Value }\end{array}$ & Sig. \\
\hline $\begin{array}{lr}\text { Nature of } & \text { Ownership and } \\
\text { Sustainable } & \text { Manufacturing } \\
\text { Practices } & \end{array}$ & $\begin{array}{l}4.780^{* *} \\
\text { (t-value) }\end{array}$ & .000 \\
\hline $\begin{array}{l}\text { Investment and Sustainable } \\
\text { Manufacturing Practices }\end{array}$ & $\begin{array}{l}5.143^{* * *} \\
\text { (F-Value) }\end{array}$ & .000 \\
\hline $\begin{array}{lr}\text { Business } & \text { Establishment } \quad \text { and } \\
\text { Sustainable } & \text { Manufacturing } \\
\text { Practices } & \\
\end{array}$ & $\begin{array}{l}4.952^{* *} \\
\text { (F-Value) }\end{array}$ & .000 \\
\hline $\begin{array}{lrr}\text { Number } & \text { Employees } & \text { and } \\
\text { Sustainable } & \text { Manufacturing } \\
\text { Practices } & & \\
\end{array}$ & $\begin{array}{l}5.065^{* *} \\
\text { (F-Value) }\end{array}$ & .000 \\
\hline $\begin{array}{l}\text { Annual Turnover and Sustainable } \\
\text { Manufacturing Practices }\end{array}$ & $\begin{array}{l}4.846^{* * *} \\
\text { (F-value) }\end{array}$ & .000 \\
\hline
\end{tabular}

** Significant at $1 \%$ level

The $\mathrm{t}$-value and $\mathrm{F}$-values are explicating that significant difference exit in sustainable manufacturing practices amongst profile of MSMEs.

\section{IMPACT OF SUSTAINABLE MANUFACTURING PRACTICES ON FINANCIAL PERFORMANCE OF MSMES}

To evaluate impact of sustainable manufacturing practices on financial performance of MSMEs, multiple regression analysis is used and the results are given inTable- $8 . \mathrm{R}^{2}$ and adjusted $R^{2}$ are 0.57 and 0.55 which reveal the regression model has good fit and 55 per cent of variation in dependent variable is shared by independent variables. F-value of 15.824 is illustrating the model is significant at one per cent level.

Table-8. Impact of Sustainable Manufacturing Practices on Financial Performance of MSMEs

\begin{tabular}{|l|l|l|l|}
\hline $\begin{array}{l}\text { Sustainable } \\
\text { Manufacturing } \\
\text { Practices }\end{array}$ & $\begin{array}{l}\text { Regression } \\
\text { Co-efficients }\end{array}$ & t-Value & Sig. \\
\hline Intercept & $1.016^{* *}$ & 9.835 & .000 \\
\hline
\end{tabular}

\begin{tabular}{|l|l|l|l|}
\hline $\begin{array}{l}\text { Cleaner Production } \\
\left(\mathrm{X}_{1}\right)\end{array}$ & $.542^{* *}$ & 6.716 & .000 \\
\hline Eco-Efficiency $\left(\mathrm{X}_{2}\right)$ & $.484^{* *}$ & 6.102 & .000 \\
\hline $\begin{array}{l}\text { Relation with } \\
\left.\text { Employee( } \mathrm{X}_{3}\right)\end{array}$ & $.391^{* *}$ & 5.048 & .000 \\
\hline $\begin{array}{l}\text { Relation with Supplier } \\
\left(\mathrm{X}_{4}\right)\end{array}$ & $.435^{* *}$ & 5.830 & .000 \\
\hline $\begin{array}{l}\text { Relation with Customer } \\
\left(\mathrm{X}_{5}\right)\end{array}$ & $.378^{* *}$ & 4.964 & .000 \\
\hline $\mathrm{R}^{2}$ & 0.57 & - & - \\
\hline Adjusted $\mathrm{R}^{2}$ & 0.55 & - & - \\
\hline $\mathrm{F}$ & 15.824 & - & .000 \\
\hline
\end{tabular}

Significant at $1 \%$ level

The findings make clear that cleaner production, eco-efficiency, relation with supplier, relation with employee and relation with customer have positive and significant impact on financial performance of MSMEs at one per cent level.

\section{V.CONCLUSION}

The foregoing analysis elucidate that cleaner production, eco-efficiency, relation with employee, relation with supplier and relation with customer are sustainable manufacturing practices adopted by MSMEs. Significant difference is prevailing amongst profile of MSMEs and their sustainable manufacturing practices. Cleaner production, eco-efficiency, relation with supplier, relation with employee and relation with customer are having significant and positive impact on financial performance of MSMEs. To improve sustainable manufacturing practices, MSMEs should reduce their solid waste and usage of materials and they must have efficient compliance for environment and adopt environment regulations properly. Furthermore, MSMEs should provide sufficient salary and good work life balance to their employees and they must direct suppliers to act on environment problems and send appraisal of environmental performance to them. In addition, MSMEs should completely avoid harmful effects of their products and these measures will improve financial performance of MSMEs.

\section{REFERENCES:}

[1] Alay, C., Säfsten, K., \& Johansson, G. (2017). Conceptual sustainable production principles in practice: Do they reflect what companies do?, Journal of Cleaner Production, 141, 693-701.

[2] Chen, M. K., \& Shih, L. H. (2007). An empirical study of implementation of green supply chain practices in the electrical and electronic industry and their relation to organizational performances. International Journal of Environmental Science and Technology, 4(3), 383-394.

[3] Despeisse, M, Mbaye, F., Ball, P.D., \& Levers, A. (2012). The emergence of sustainable manufacturing practices. Production, Planning and Control, 23(5), 354-376.

[4] Habidin Nurul Fadly, Zubir Anis Fadzlin Mohd, Fuzi Nursyazwani Mohd, Latip Nor Azrin Md, \& Azman Mohamed Nor Azhari. (2015). Sustainable manufacturing practices in Malaysian automotive industry: Confirmatory factor analysis, Journal of Global Entrepreneurship Research, 5(14), 1-13.

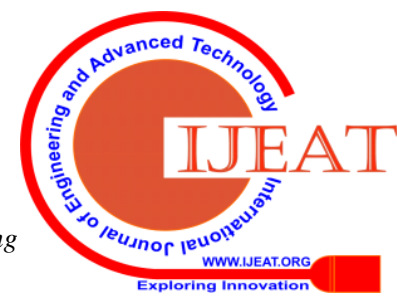


[5] Hashidah, Syukor, \& and Razali. (2017). Modeling sustainable manufacturing practices towards economy sustainability performance. ARPN Journal of Engineering and Applied Sciences, 12(14), 4214-4218.

[6] Jamian, R., Ab Rahman, M.N., Md Deros, B., \& Nik Ismail, N.Z. (2012). A conceptual model towards sustainable management system based upon $5 \mathrm{~S}$ practice for manufacturing SMEs. Asia Pacific Journal of Operations Management, 1(1), 19-31.

[7] Joung, C., Carrell, J., Sarkar, P., \& Feng, S. (2013). Categorization of indicators for sustainable manufacturing, Ecological Indicators, 24,148-157.

[8] Lopez-Gamero, M. D., Molina-Azorin, J. F., \& Claver-Cortes, E. (2009). The whole relationship between environmental variables and firm performance: competitive advantage and firm performance as mediator variables. Journal of Environmental Management, 90(10), 3110-3121.

[9] Millar, H. H., \& Russell, S. N. (2011). The adoption of sustainable manufacturing practices in the Caribbean. Business Strategy and the Environment, 20, 512-526.

[10] Nordin, N., \& Adebambo, H.O. (2016). Descriptive analysis of sustainable manufacturing indicators in Malaysian manufacturing firms. Journal of Mechanical Engineering and Sciences, 10(2), 2126-2133.

[11] Nordin, N., Ashari, H., \& Rajemi, M.F. (2014). A case study of sustainable manufacturing practices. Journal of Advanced Management Science, 2, 12-16.

[12]Norsiah Hami, Fadhilah Mat Yamin, Shafini Mohd Shafie, Mohd Razali Muhamad,\& Zuhriah Ebrahim. (2018). Sustainable manufacturing practices among SMEs in Malaysia. International Journal of Technology, 8, 1658-1667

[13] Schoenherr, T., \& Talluri, S. (2012). Environmental sustainability initiatives: A comparative analysis of plant efficiencies in Europe and the U.S. Science, 35(1), 87-108.

[14] Suzana N Russell, \& Harvey H Millar. (2014). Exploring the relationships among sustainable manufacturing practices, business performance and competitive advantage: Perspectives from a developing economy. Journal of Management and Sustainability, 4(3), 37- 53

\section{AUTHORS PROFILE}

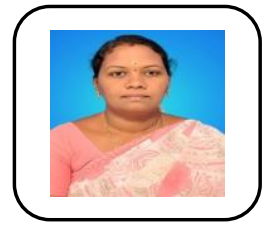

She is Dr.S.RANI M.Com M.Phil., B.Ed MBA, PGDCA, Ph.D. She has published two of Scopus indexed journals, one of UGC listed journal, and she got the Nehru Best Faculty Award, Exclusively for Commerce, Management and Computer Applications, Nehru Group of Institutions, Coimbatore, she has published 9 papers in various journals and she has published around 30 papers in various National \& International conferences and Seminars. She has attended Seven Workshops \& Six Faculty Development Programs. She has Chairperson on the theme Building Inclusive Leadership Ecosystem for Global Business in an International Conference organized by NIT Coimbatore. Acted as a Chairperson of Board of Studies in Department of Commerce in Kalasalingam Academy of Research and Education (Kalasalingam University) at Krishnankoil. She has Advisory Board Member in Nehru Institute of Technology in Coimbatore. She has acted as the Head of the Department Of Commerce at Kalasalingam Academy of Research And Education from 2015 to 2018. She has State Organizer in Consumer Club State Organizer South Indian Consumer \& People Rights Protection Council and She has a Life time Member of Indian Accounting Association, Salem. 